\title{
INSTITUTE OF PRESIDENCY IN HUNGARY AND UKRAINE: POLITICAL AND LEGAL ASPECT
}

\author{
Sergii Tellis ${ }^{1}$ \\ ${ }^{1}$ Postgraduate student of Law Departament, «KROK» University, Kyiv, Ukraine, \\ serg.alexandrovich1@gmail.com ORCID 0000-0003-3090-3940
}

\begin{abstract}
The article provides a comparative study of the constitutional powers granted to presidents in Ukraine and Hungary in the context of the political and legal aspect, and also an attempt to appraise the role of subjective factors involved in the exercise of state power and transformation of the presidency institute of the aforementioned states. The aim of the article: to comparative study of the constitutional and legal status of Hungarian and Ukrainian presidents in the political and legal context and performing an appraisal of the personal impact exerted by the head of state on the government of the above-said countries. The research methodology: to observation and generalization; ordering of all basic elements; method of scientific generalization, which made it possible to formulate conclusions. As a result, it is established that the institution of the presidency in Ukraine is the core of the executive branch, which dominates the state system. In Hungary, the executive and legislative branches make up a political bloc (alliance) which is counterbalanced in certain relations by the constitutional court and judicial power. The subjective factor, namely personal qualities of presidents - career path, role perception, interpretation of powers - determines the political heft of the head of state. Subject to sufficient individual traits, a constitutionally "weak" president is able to influence the country's development concept and the positioning strategy on the global scene.
\end{abstract}

Keywords: institute of presidency, president of Hungary, president of Ukraine

JEL Classification: M10, M11, M21, H79, P35, E69

Formulas: 0; fig.: 0; tabl.: 1; bibl.: 16

Introduction. A comparative study of the specific ways the machinery of government functions in countries with positive experience in establishing the institute of presidency will help make the search for those mechanisms in Ukraine meaningful and understandable. Most scientists engaged in the research of the institute of presidency in post-Soviet Eastern European countries identify Hungary as an example of successful implementation of the parliamentary-presidential republic model.

The institute of presidency researchers point out that presidents have substantial personal influence on the state policy. With that in mind, the above-mentioned phenomenon of the subjective impact on the development of the presidency institute is worth attention and appraisal.

The comparison study in terms of the political and legal aspect of the presidency institutes of Hungary and Ukraine will enable an appraisal of the legal dissimilarities and of the influence of subjective factors on the exercise of public authority in the countries under consideration.

Literature review. Specific aspects of the political and legal status of the institute of presidency in Ukraine are covered in the works by D. M. Belov, Yu. M. Bisaga, A. I. Kudryachenko and Ye. I. Golovakha. The functioning of the state 
mechanism in Hungary and the president's role are researched in Csink Lóránt's monograph. A comparative study of the constitutional legal status of the Hungarian presidency is offered in the papers by Ye. G. Uliashina and Szilárd Popovics. The state system of Hungary and specific legal differences between the presidencies of Hungary and Ukraine were researched by D. I. Tkach.

The research of functioning of the presidency institute in post-Soviet Eastern European countries had not yet included a comparative study of the institute of presidency in Hungary and Ukraine in the context of the political and legal aspect.

Aims. The article is aimed at conducting a comparative study of the constitutional and legal status of Hungarian and Ukrainian presidents in the political and legal context and performing an appraisal of the personal impact exerted by the head of state on the government of the above-said countries.

Methods. To solve this goal, the following research methods were used: observation and generalization; ordering of all basic elements; method of scientific generalization, which made it possible to formulate conclusions.

Results. Scope of president's power in the system of state bodies. Based on the comparative study we will identify the commonalities and differences of the constitutional powers of Ukrainian and Hungarian presidents. The basic criteria for determining the scope of head of state's authority are: 1) capacity to influence the executive branch; 2) capacity to appoint the government; 3) capacity to influence the legislature; 4) power to initiate legislation and right of veto; 5) president's foreign policy activity; 6) capacity to impact other state structures.

The comparative study of constitutional presidential powers has revealed that the overall scope of authorities granted to the president of Ukraine exceeds substantially the scope of authorities granted to the president of Hungary (Table 1).

The scope of the Ukrainian president's powers, even regardless of the fact that a portion thereof requires countersigning by the prime minister and competent minister, testifies to the functional dominance of the presidency institute in the power machinery of Ukraine. Based on the Constitution of Ukraine as of 1996 the president is entitled to appoint and dismiss single-handedly the prime minister and practically all key officials of the state, to cancel government instruments, to create and reorganize ministries, agencies and other bodies of the state executive branch. The 1996 Constitution of Ukraine, unlike the Hungarian one, provides the president with controls over state authorities, primarily over the executive power. The president of Ukraine has the right to create laws without countersigning, has the power of veto and has significant influence on the formation of the Constitutional Court and of the court authorities in general.

The competences of the Ukrainian president in the executive branch, complemented by the practically insuperable right to veto laws adopted by the Verkhvona Rada, makes the president's institute a central political institution in control of the political and economic life of Ukraine. 


\section{Comparison of the main provisions of the Constitution of Hungary and Ukraine}

\begin{tabular}{|c|c|}
\hline Constitution of Hungary (Act XX of 1949) [15] & Constitution of Ukraine (adopted on 28.06.1996) [16] \\
\hline \multicolumn{2}{|c|}{ Government } \\
\hline $\begin{array}{l}\text { recommends the candidate for the office of Prime Minister [15, Article } 33 \text { (3)] } \\
\text { the Prime Minister is elected by the National Assembly } \\
[15 \text {, Article } 19(3) \mathrm{k})]\end{array}$ & $\begin{array}{l}\text { appoints the Prime Minister of Ukraine; } \\
\text { terminates the authority of the Prime Minister of Ukraine and adopts a decision on his or her } \\
\text { resignation [16, Article 106, para.9] } \\
\text { Verkhovna Rada authorities include giving consent to the appointment of the Prime Minister of } \\
\text { Ukraine by the President of Ukraine [16, Article 85, para.12] }\end{array}$ \\
\hline
\end{tabular}

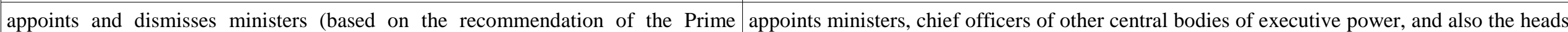
Minister) [15, Article 33 (4)]

of local state administrations (on the submission of the Prime Minister), and terminates their the Prime Minister appoints a Deputy Prime Minister from among the ministers [15, authority in these positions [16, Article 106, para.10]

Article 33 (2)]

establishes and liquidates ministries and bodies of executive power (on the submission of the

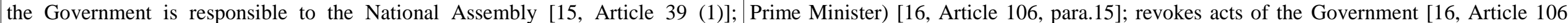
members of the Government are responsible to the Government and the National para.16]

Assembly [15, Article 39 (2)]

The Government is accountable to the President and is guided, inter alia, by acts of the President of Ukraine [16, Article 113]

members of the Government shall take an oath before the National Assembly [15, The Government tenders its resignation to the newly-elected President [16, Article 115] Article $33(5)]$

\section{Judicial power}

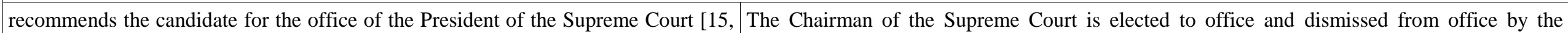

Article 48 (1)

Plenary Assembly of the Supreme Court by secret ballot, by the procedure established by law

appoints Deputy Presidents of the Supreme Court (based on the recommendation [16, Article 128]

made by the President of the Supreme Court) [15, Article 48 (1)] $\quad$ appoints professional judges [16, Article 128]

appoints professional judges [15, Article 48 (2)] (based on the recommendation appoints one-third of the composition to the Constitutional Court [16, Article 106, para.22]

made by the President of the Supreme Court)

the President of the Supreme Court is elected by the National Assembly [15, Article

$19(3) \mathrm{k})]$

The Chairman of the Constitutional Court of Ukraine is elected by secret ballot at a special

members of the Constitutional Court are elected by the National Assembly [15, Constitutional Court [16, Article 148].

Article 19 (3) k)]

the President of the Constitutional Court is elected by Court members from among

themselves by secret ballot [15, Article 32 / A (5)]

\section{Prosecutor's Office}

recommends the candidate for the office of the Prosecutor General [15, Article 51 appoints and dismisses the Prosecutor General [16, Article 106, para.11]

(1)

the authorities of Verkhovna Rada of Ukraine include granting consent for the appointment of

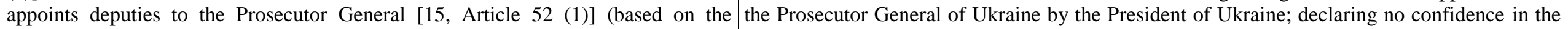




\section{Constitution of Hungary (Act XX of 1949) [15]}

recommendation made by the Prosecutor General)

the Prosecutor General is elected by the National Assembly [15, Article 19 (3) k)]

A majority of two thirds of the votes of the Members of Parliament present is

required to pass the law on the Public Prosecution Service and on the Service

Relation of Public Prosecutors [15, Article 53 (4)]

\section{National Bank}

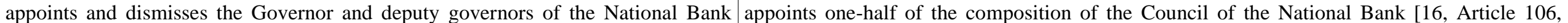
[15, Article 30/A(1)i)] with countersignature of the Prime Minister or responsible para.12]

Minister [15, Article 30/A (2)]

the authorities of Verkhovna Rada of Ukraine include appointment and dismissal of the Chairman of the National Bank of Ukraine on the submission of the President of Ukraine [16, Article 85, para.18]

\section{Supervisory Bodies}

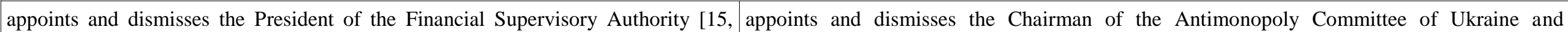
Article 30/ A. (1) i)] with countersignature of the Prime Minister or responsible Minister [15, Article 30 / A. (2)]

Chairman of the State Property Fund of Ukraine [16, Article 106, para.14]

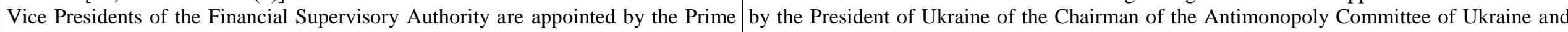
Minister [15, Article 40 / D. (2)]

President and Vice Presidents of the State Audit Office are elected by the National Assembly [15, Article 19 (3) k)]

the President of the National Media and Infocommunications Authority

is appointed by the Prime Minister [15, Article 40/ E (2)]

Chairman of the State Property Fund of Ukraine [16, Article 85, para.24]

\section{State media}

appoints and dismisses, with the consent of the Verkhovna Rada, the Chairman of the State Committee on Television and Radio Broadcasting of Ukraine [16, Article 106, para.14] appoints one-half of the composition of the National Council of Ukraine on Television and Radio Broadcasting [16, Article 106, para.13]

the authorities of Verkhovna Rada include granting consent for the appointment and dismissal by the President of Ukraine of the Chairman of the State Committee on Television and Radio Broadcasting of Ukraine [16, Article 85, para.24]

legislation may be initiated by the President [15, Article 25 (1) ]

\section{Legislature}

ratifies and orders the promulgation of laws adopted by the National Assembly [15, Ukraine as urgent are considered out of turn by the Verkhovna Rada [16, Article 93

Article 26 (1)] or refers the law, along with his/her comments, to the National signs laws adopted by the Verkhovna Rada of Ukraine [16, Article 106, para.29]

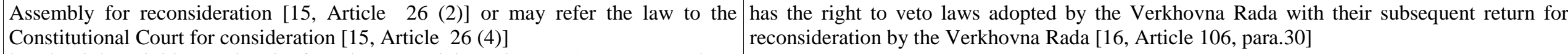

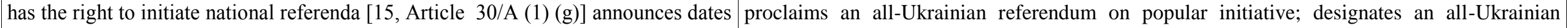


Constitution of Hungary (Act XX of 1949) [15]

of national referenda [15, Article $30 / \mathrm{A}(1)(\mathrm{d})]$

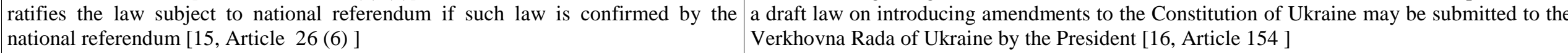

\section{Regional and District Executive Power}

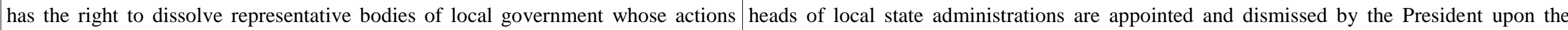
have been found unconstitutional [15, Article 19 (3) 1)] (based on the

Government's recommendation)

$19(3)-1)$ ] (based on the submission of the Government [16, Article 118 ]

In the exercise of their duties, the heads of local state administrations are responsible, in

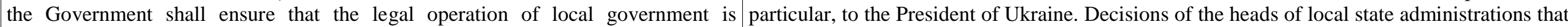
monitored [15, Article 35 (1) d)]; the fundamental rights of local governments may contravene the Constitution may be revoked by the President [16, Article 118 ]

be restricted by the Government [15, Article 44/C]

Local state administrations on their respective territory ensure, inter alia, the execution of acts of the President [16, Article 119 para.1 ]

\section{International Relations, Participation in the Execution of International Agreements}

the President represents the State of Hungary [15, Article 30/ A (1) (a)]

the President represents the state in international relations, administers the foreign political activity of the State, conducts negotiations and concludes international treaties of Ukraine [16, Article 106, para.3]

acts of the President of Ukraine issued within the limits of authority as are cosigned by the

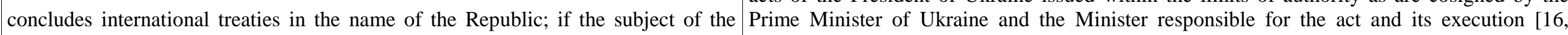
treaty falls within its legislative competence, prior ratification by the Parliament is Article 106]

necessary for conclusion of the treaty [15, Article 30/ A (1) (б)]

adopts decisions on the recognition of foreign states [16, Article 106, para.4]

appoints and dismisses heads of diplomatic missions to other states and to international

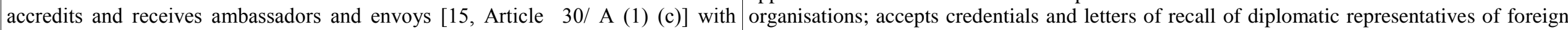
countersignature of the Prime Minister or responsible Minister [15, Article 30/ A states [16, Article 106, para.5]

$(2)$ 
Management of the foreign policy activities, national security and defense are within the sole competency of the president. The executive branch of power has the greatest influence on the state administration.

Under the Hungarian constitutional law, in our opinion, the president's role in the system of checks and balances of the state power is more of a coordinating one; his/her authorities are rather neutral in terms of choice and influence. The president of Hungary can nominate candidates for key government positions and is granted a weak suspensive veto on ratified legislature.

The Hungarian constitution places substantial emphasis on the execution of personnel decisions by the president while staff recruitment and scheduling are performed by the government coalition [1, page 116]. For all of his/her activities and orders the president needs a visa (countersignature) of the prime minister or relevant ministers. He/she can only revoke appointments or other staffing decisions when the decision will seriously damage the functioning of the state's democracy mechanism. The Hungarian president's capacity to interfere with the activities of the government and executive branch is limited by the Constitution; the National Assembly is the executive power holder.

Functional dominance in the power machinery is attributed to the government coalition. The latter and the prime minister virtually have a monopoly on the Republic's management decisions economy- and politics-wise. From the political viewpoint the president's maneuvering capacities are restricted by the fact that the parties able to form the government are in coalition and put forward a single candidate for the prime minister's position, so the president's powers under the public law to appoint head of government do not provide for an independent decision. The National Assembly is the central political institution in control of Hungary's political and economic life.

Considering the constitutional law aspect, the Hungarian president's political heft should be very moderate (as compared with the president of Ukraine), and his/her role in the national checks and balances system is limited to arbitration, as regarding the state's constitutional functioning.

Personal impact of presidents on the state policy and actual effects of the impact: Ukraine. Researchers note a certain discordance between constitutional provisions and political practice [2]. The subjective role of the president's personality always has transformative effect on the political climate and socio-political development in the country [3].

To understand the genesis and essence of the researched models of the presidency institute, it is necessary in our opinion to investigate the institutes in the context of presidents' personality in combination with the socio-cultural and political realities.

Formally, Ukraine chose a model of democratic governance which was not consistent with the country's informal institutes - there were persistent totalitarian traditions. Researchers have been voicing different opinions regarding the dominant influence in the problematic of implementation of the selected model and political system establishment in Ukraine [4][5][6][7]. 
We believe that objective and subjective factors involved in the transitioning from a parliamentary-presidential republic to the presidential one are as follows: objective factors - socio-cultural conditions of the post-totalitarian system, subjective ones - personal traits of the second President L. Kuchma.

Ukraine's institute of presidency became the nucleus of executive power, largely thanks to the personal qualities of the second president [8]. It should be noted that this is partly due to his longest presidency tenure and partly due to the fact that it was during that period of 1994-2004, according to researchers, that the institutional conditions leading to the establishment of the current political system in Ukraine were shaped.

The functioning of the presidency institute does not always fit within the framework of the president's formalized authorities. The president's subjective perception of order and justice, goals and means has essential influence on the forms and methods of exercising state power.

The formal model of state functioning was changed repeatedly: the 2004 Constitution allocating the president's powers to Verkhovna Rada and the government, restitution of the 1996 Constitution in 2010 which restored the authoritarian institute of presidency, and another reversion to the 2004 Constitution in 2014. Meanwhile, the practical state functioning model, namely the governance forms and methods, emerged in our opinion during the tenure of the second president of Ukraine and still remains in the framework of public governance and in sociopolitical life.

The president can take a considerably active part in the foreign policy branch. For instance, over the period from June 1994 to January 2005 Ukraine's foreign policy activities were fully dependent on the Ukrainian president [3]. From May 12, 1998 to January 1, 2005 Verkhovna Rada registered 553 bills, including 245 international agreements, which were initiated by the president [9].

Researchers note that the so-called "multi-vector approach" announced by the president in practice manifested itself at the time as uncertainty of the state's foreign policy [6, pages 776-785] [10].

In our opinion, lack of the country's clear positioning on the international scene was caused by the president attributing his personal sense of opportunities to the actual state of affairs. It was due to the personal traits of the incumbent president that the foreign policy of the time was dominated by uncertainty and lack of positioning strategies in the international context. There could have been intrinsic reasons to refrain from giving straight answers to the questions of more powerful neighbors but this does not mean there is no need for a nationally focused agenda in the foreign policy activities.

It is worth mentioning specifically that the foreign policy uncertainty and lack of a uniform positioning strategy on the international scene have negative effects in the context of succession. The elites failing to approve the state's development concept and its position in the international community contribute to the future risks during the transition of power which cannot be insured against with the personal relations established by the previous individuals in power. 
Considering the obvious disharmony between constitutional and legal provisions and the political practice, formal political institutes do not assure legal implementation of the power transit in the country.

Personal impact of presidents on the state policy and actual effects of the impact: Hungary. Researchers believe that Hungarians chose the presidentialparliamentary form of rule as it permits to control the executive power with maximum efficiency through democratic institutes and to prevent voluntarism and arbitrariness of authorities [1, page 115].

The constitutional powers of the Hungarian president are significantly restricted and can only be exercised if countersigned, and the limitation of his/her political heft is contingent on the party policy logic - the winning party nominates their leader for prime minister while the president is elected by the parliamentary majority, guided by political and constitutional consensus. According to the formal governance model of Hungary, the constitutional and political center of gravity is evidently concentrated around the head of government while the president remains a symbolic and representative entity. In practice intrinsic and human factors can substantially transform the selected model.

According to research, election of the Hungarian president in 1990 was preceded by the consensus of two major political parties - the Hungarian Democratic Forum and the Alliance of Free Democrats. Nomination of Árpád Göncz for president was a political compromise between the winning party and opposition [11].

The oppositional politician was elected the president of the Republic by parliamentary majority, creating an adequate opportunity to use the presidential office as a political counterbalance in the governmental system although the president is not a counterbalance in the constitutional law logic. Objective factors enabled the opportunities; however, according to researchers, it was the individual traits of Árpád Göncz that attached real political weight to the presidency [12].

Of particular use is a monograph by Ukrainian diplomat Dmytro Tkach dedicated to the politology study of political transformations in Hungary. The researcher points out that during various periods of the recent epoch the parties in office were built upon personal commitment to the party leader and severe discipline. Leaders of incumbent parties gravitated towards single-handed steering of the party, defining its policies, agenda and methods of the political race; they pursued to carry the dictate inside their party to the dictate in the government, including staffing matters [1, page 95]. Mr. Tkach also notes that the practice of forming the parliament majority which in its turn forms the government majority helped eliminate the opposition of the branches of power, laying the groundwork for meaningful work [1, page 106].

As for the president's legislative activity, Árpád Göncz opposed 10 bills during his two terms in office: he addressed the Constitutional Court 8 times and sent a bill to the National Assembly for review twice.

Speaking of the president's influence on the executive branch, researchers mention the political struggle around the scope of authorities granted to the president of state and the conflict caused by obstruction of the appointment of mass media 
presidents, during the government of Hungary's 1990-1993 Prime Minister József Antall. The fight resulted in Constitutional Court resolutions further restricting the president's constitutional powers [13].

During the subsequent governments of G. Horn (1994-1998) and V. Orbán (1998-2002) there were no attempts on the part of the president to transform key political institutes of the state while the prime minister predominantly focused on economic issues [14].

In our opinion, the state governance system of Hungary at the time reached an equilibrium, with the interaction of branches acquiring optimum characteristics and the work of institutes becoming meaningful.

Hungary's foreign policy invariably includes chief priorities: Euro-Atlantic integration, relations with neighboring countries, protection of the rights of Hungarians residing in those countries.

Guided by the above priorities, each new government during the 1990-1999 period identified three basic directions in the domain of foreign policy: integration into European and Euro-Atlantic institutions, establishment of neighborly relations with bordering states, defense of the rights of the Hungarian national minorities in the said states.

From the viewpoint of legal analysis, the authorities the Constitution of Hungary grants to the president make him a symbolic representative subject. However, with subjective factors coming into play, the institute of presidency can transform into an active component of the political and legal system, and impact the state's development concept and positioning strategy on the international scene.

Discussion. It should be stressed that with the above power model the risks involved in the transition of power are substantially mitigated. The party-state leadership logic provides for the development of the political establishment in the country and reaching agreement on the open rules of the game - political practice conforms to the constitutional and legal provisions.

Conclusions. The comparative study of constitutional powers of presidents reveals that generally the scope of authorities granted to the Ukrainian president far exceeds that of the Hungarian president. The institute of presidency in Ukraine constitutes the nucleus of executive power which dominates the state system. In Hungary, the executive and legislative branches make up a political bloc (alliance) which is counterbalanced in certain relations by the constitutional court and judicial power. The subjective factor, namely personal qualities of presidents - career path, role perception, interpretation of powers - determines the political heft of the head of state. Subject to sufficient individual traits, a constitutionally "weak" president is able to influence the country's development concept and the positioning strategy on the global scene.

\section{References:}

1. D. I. Tkach. Modern Hungary in the Context of Social Transformations: Monograph / I. F. Kuras Institute of Political and Ethno-national Research, National Academy of Sciences of Ukraine. - K.: MAUP, 2004, 504 pages. 
2. G. I. Zelenko. Institute of Presidency in Ukraine in the Contemporary Historical and Politology Discourse of Ukraine. - Ukraine, Kyiv, 2017. - 20 pages. [Electronic resource] - Available at: http://elibrary.ivinas.gov.ua/442/1/Zelenko_2017_3.pdf

3. D. I. Tkach. Role of Subjective Factor in Foreign Policy of Ukraine in times of President Leonid D. Kuchma. 2018. [Electronic resource] - Available at: https://spsciences.io.ua/s2631968/tkach_dmytro_2018_._role_of_subjective_factor_in_foreign_policy_of_uk raine_in_times_of_president_leonid_d._kuchma._social_and_human_sciences._polishukrainian_scientific_journal_02_18_

4. Political System and Civic Society: European and Ukrainian Realities: Monograph / Under the general editorship of A. I. Kudryachenko, Doctor of History, Professor. - K.: NISS, 2007. - 396 pages. [Electronic resource] - Available at: http://old.niss.gov.ua/book/Kudr_mon/05.pdf

5. D.M. Belov, Yu. M. Bisaga. Experience of Legal Constitutional Regulation of the Presidential Institution in Foreign Countries. Monograph. - Uzhgorod: Lira, 2007. - 275 pages.

6. Ye.I. Golovakha. Political System for Ukraine: Historical Experience and Challenges of Modernity [comprehensive research] / [O. G. Arkusha et al.; editorial board: V. M. Litvin (head) et al.]; National Academy of Sciences of Ukraine, Institute of History of Ukraine, I. F. Kuras Institute of Political and Ethno-national Research. - Kyiv: Nika-Center, 2008. - 986 pages. [Electronic resource] - Available at: http://irbis-nbuv.gov.ua/ulib/item/UKR0001524

7. B.L. Demianenko. Genesis of the Institute of Presidency in Ukraine. [Electronic resource] Available at: http://dspace.nbuv.gov.ua/bitstream/handle/123456789/26663/03Demyanenko.pdf? sequence $=1$

8. S.O. Tellis. Institute of Presidency in Ukraine 1991-2014: Historical and Legal Aspects, Subjective Factors and their Consequences (Part 2). 2018. [Electronic resource] - Available at: http://library.krok.edu.ua/media/library/category/zhurnali/pravnychyi-visnyk-universytetukrok/pravnychyi-visnyk-universytetu-krok-n30.pdf

9. Bills registered by Verkhovna Rada of Ukraine. [Electronic resource] - Available at: (http://w1.c1.rada.gov.ua/pls/zweb2/webproc2)

10. M. Aleksieyevets, J. Seko. Ukraine's Foreign Policy: From Multidirectional to No Alternative. [Electronic resource] Available

at: http://dspace.tnpu.edu.ua/bitstream/123456789/6936/1/Aleksieyevets.pdf

11. Gulyás András. Göncz Árpád a demokráciáért, a demokrácia kialakulásáért [Electronic resource] - Available at: http://www.gonczarpad.hu/goncz_arpad_a_demokraciaert_a_demokracia_kialakulasaert\&prev=sear ch

12.Tükör által világosan. [Electronic resource] - Available at: http://www.gonczarpad.hu/tukor_altal_vilagosan

13. LŐRINCZ TAMÁS. Göncz Árpád mindig keményen harcolt. 2015. [Electronic resource] Available at: http://www.origo.hu/itthon/20151008-igazi-harcos-volt-goncz-arpad.html

14. M. A. Usievych. A Decade of Reforms in Hungary. The 1990s. // Modern and Contemporary History. - 2002. - \#5. - Pages 80-97. [Electronic resource] - Available at: https://www.ckofr.com/istoriya/213-desyatiletie-reform-v-vengrii-90-e-gody-20-veka?showall=1

15. Constitution of the Republic of Hungary (Act XX of 1949). The 1949 edition of the Constitution incorporates all amendments implemented up to 2010 inclusive. [Electronic resource] - Available at: http://www.wipo.int/wipolex/ru/text.jsp?file_id=190398

16. Constitution of Ukraine. Document 254к/96-BP, first edition = adopted on 28.06.1996. [Electronic resource] - Available at: http://zakon.rada.gov.ua/laws/show/254к/96Bp/ed19960628?lang=uk 